\title{
Sassafras Oil
}

National Cancer Institute

\section{Source}

National Cancer Institute. Sassafras Oil. NCI Thesaurus. Code C74290.

The oil extracted from the roots of any of the three species of Sassafras. Due to the toxic compound safrole at high concentration in the oil, sassafras oil is banned for use in the United States. 